\title{
Application of the system of environmental economic accounting for water SEEAW to the Spanish part of the Duero basin: Lessons learned
}

\author{
D.J. Vicente, L. Rodríguez-Sinobas, L . G a r r o t e , R. S á n c h e z
}

GRAPHICAL A B S T RACT

- Elaboration of SEEA water asset accounts and application on the Spanish Duero basin.

- Methodology based on three hydrological/hydraulic models (SIMPA, ASTER, and SIMGES).

- Yearly and monthly balances to study inter-annual and seasonal variability.

- Lessons learned about spatial disaggregation and suggestions on how to proceed.

- Analysis of water uses, particularly nonconsumptive and rainfed agriculture uses.

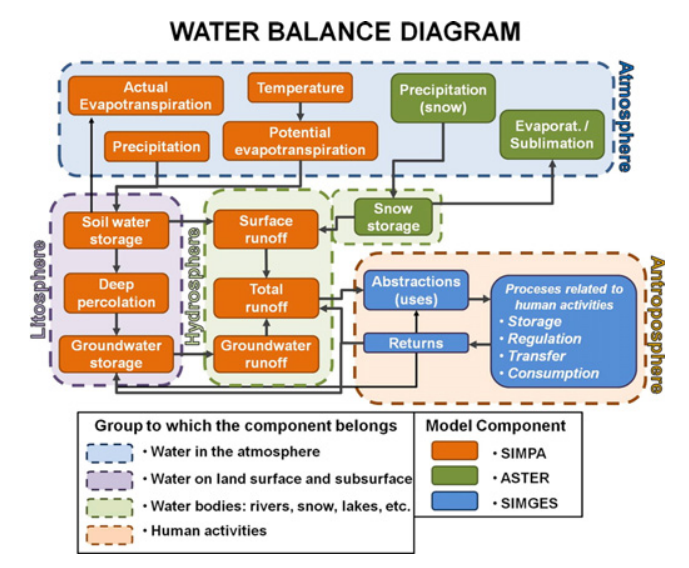

Keyworks:

System of Environmental-Economic

Accounting for Water

River basin management planning

Science-policy interfacing

Hydrological modeling

Water resources management

Duero River basin

\begin{abstract}
A B S T R A C T
The System of Environmental-Economic Accounting for Water (SEEA-W) consists of an agreed international framework for organizing hydrological and economic information in a coherent and consistent manner. The methodology yields to the SEEA-W physical tables focusing on the quantitative assessment of the stocks and their changes in a river basin during the accounting period. For that purpose, the information on the abstraction and water discharge is linked with the environment water stocks, which assesses how current levels of abstraction and discharge affect such water stocks. This study presents the methodology and results to fill out the SEEAW tables for asset accounts on the Spanish Duero basin. Duero is a transboundary river between Spain and Portugal where $80 \%$ of its basin area $\left(78,860 \mathrm{~km}^{2}\right)$ runs into the Spanish territory. The Spanish part is divided in five zones and 13 management systems. The methodology applied the three models used by the Spanish Water Authorities for the planning and allocation of water resources in Spain: 'SIMPA' model (rainfall-runoff model), 'ASTER' model (hydro-meteorological model related to snow processes) and 'SIMGES' model (water management simulation model). The required information was collected with the support from the Duero River basin Authority and the Spanish Ministry of Agriculture. Special care was paid to issues such as: inter-annual variability, the selection of spatial and temporal scale, seasonality, disaggregation of human abstractions into use's type, and transboundary agreements. The results highlighted some drawbacks in the SEEAW methodology for the Duero basin. However, the developed balances are a valuable tool to support the decisions of the Spanish Duero basin
\end{abstract}




\section{Introduction}

Water supply management is becoming a severe problem in many parts of the world, due to the ever-increasing rates of water demand together with the changes in climate during the past decades. Climate change is projected to alter water availability varying its impact from region to region (ICCP, 2014). Europe is concerned by this situation especially affecting Mediterranean area (Ludwig and Roson, 2016; Iglesias et al., 2007). Water availability and scarcity has progressively emerged as a key aspect in European Union water policy making and implementation, as noted in the strategic objectives of latest European Directives and Communications (Quevauviller, 2014) - e.g. 'A Blueprint to Safeguard Europe's Water Resources' (EC, 2012), 'EU Water Framework Directive' (WFD) (EP, 2000), 'White Paper - Adapting to climate change: Towards a European framework for action' (EC, 2009), among others. The extent of its importance is also reflected in the large number of EU-funded and national research projects directly or indirectly supporting water policies, in particular, the scientific challenges posed by the WFD (Quevauviller et al., 2012).

For this purpose, water balances or asset accounts has been identified as a key policy instrument for assessing the amount of water and its availability in a territory. In overall terms, water accounting is a tool that defines water availability and helps stakeholders and users to understand water use and benefits and costs derived from its use. Another definition was introduced by Momblanch et al. (2014) as the development of water balances in a territory that includes elements related with water use (country, river basin, etc.) reported in a certain format.

There are several water accounting methodologies developed by different countries and specialized organizations with different presentation formats of the information included (van Dijk et al., 2014). Moreover, the context in which they were conceived also differs from one another and thus the information included itself. One of the most widely accepted methods is the Water Accounting Framework (WA) proposed in 1997 by the International Water Management Institute (IWMI) (Molden and Sakthivadivel, 1999) and its improved version $($ WA +) (Karimi et al., 2013). While the former provides information on supply and use of water and relates water use to economy, the latter adds explicit spatial information on water depletion and net withdrawal processes in complex river basins.

Australia is one of the main drivers in the elaboration of water accounting methodologies. Some of the proposals launched are the Australian Bureau of Statistics (ABS) Water Accounts (ABS, 2004) and more recently, the Australian Water Accounting Standard (AWAS 1) (BoM, 2012). Both proposals address the link from physical data to economic data sets, providing specific information to water users for them to make and evaluate decisions on the allocation of water resources.

The System of Environmental-Economic Accounting for Water (SEEA-Water) (UNSD, 2012), fully coherent with the broader SEEA, emerged with a similar approach. The SEEA handbook was first published in 1993 (UN, 1993) and was revised in 2003 (EC, 2003). The SEEA 2003 is a large and complex system that covers different types of accounts. Asset accounts are intended to assess how levels of abstraction and water discharge affect the volume of water in a given territory. The water balance proposed in the SEEA-Water describes the stocks of the environmental water resources at the beginning and the end of a period (usually the hydrological year) and their changes (UNSD, 2012). The changes in stocks, in both inlets and outlets, are mainly caused for natural processes (hydrological and other exchanges between water bodies) and human activities (abstractions and returns). The first step in the development of water balances requires the assessment of the environmental water resources by the quantification of the hydrological processes. Human activities also imply exchanges involving the abstraction and return of water from/to the environment. In particular, water is abstracted from the inland water resource system, including surface water, soil water and groundwater, and water from other sources (other territories and seas). All these processes are defined in the asset classification of SEEA-W (UNSD, 2012), particularly in tables VI.1 and VI.2.

In this context, the SEEA-Water asset accounts are applied to one of the largest basins of Spain, the Duero basin. This paper focuses on the development of the physical accounts using the available data series and tools related to water basin management. In this paper, three hydrological and water management models validated for Spain and other countries worldwide were used. Detailed analyses were conducted of key aspects such as inter-annual variability, the selection of spatial and temporal scale, seasonality, disaggregation of human abstractions into use type, and transboundary agreements. Specific targets include the identification of the required information for the SEEAW system, the adaptation of the data to the scope of the environmental accounts, the documentation of the process followed to transfer the information, and the prediction of possible problems related with the lack of information.

\section{Materials and methods}

In order to process the information and estimate all the data required to fulfill the SEEAW tables, three models developed by different Spanish Water entities were used. The models integrate hydrologic and water resources management and allocation processes. The descriptions of the main characteristics of each model are presented below.

\subsection{SIMPA (rainfall-runoff model)}

Most data regarding hydrological processes, excluding those linked to snow processes, were obtained from the results of the Integrated System for Rainfall-Runoff Model (SIMPA, by its Spanish acronym) (Estrela and Quintas, 1996) developed by the Centre for Hydrographic Studies, CEDEX. It is a conceptual quasi-distributed model that reproduces monthly the essential processes of a natural hydrological cycle, implementing a classic soil moisture balance model (Témez, 1977), in a distributed way. The model was calibrated over 100 control points of the entire territory of Spain, using stations where stream flows are measured in natural regimes (Álvarez et al., 2004), enabling the monthly series of runoff in such a regime.

The model inputs are the following:

- hydrological parameters: maximum soil storage, maximum infiltration capacity or the aquifer discharge coefficient, among others;

- data on historical flows at the testing points; and

- raster layers with a spatial resolution of $1 \mathrm{~km}^{2}$ and a monthly time step of precipitation and temperature. The latter is used to determine potential evapotranspiration by combining the Thornthwaite and Penman-Monteith methods.

Then, a water balance based on a collation of transfer flows and storage flows is obtained. Surface water balance is calculated by mass conservation while aquifers are simulated as unicellular models. The structure of model results, provided as data layers of the same cell size ( $1 \mathrm{~km} \times 1 \mathrm{~km}$ ), over the period 1940-2010, is shown in Fig. 1 . 


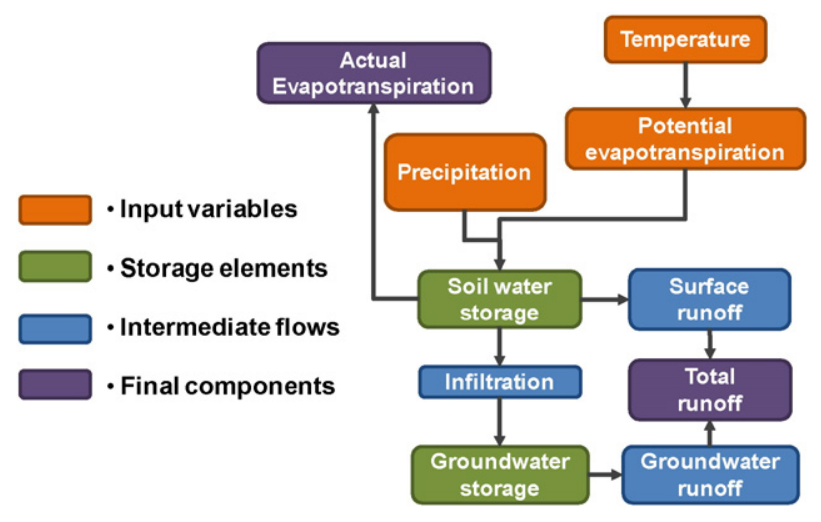

Fig. 1. Schematic structure of SIMPA model.

The SIMPA model has been applied in a number of studies (de Miguel et al., 2015; Milano et al., 2013; Gonzalez-Zeas et al., 2012) as well as on the elaboration of relevant documents at a national level like the "White Paper Book of Waters in Spain" and the "National Water Master Plans" (CHD, 2015; MMA, 2000).

\subsection{SIMGES (water allocation and management simulation model)}

SIMGES is water resources management simulation model that is integrated in the generalized Decision Support System (DSS) 'AQUATOOL' (Andreu et al., 1996) developed by Technical University of Valencia. It is used throughout the Spanish water basins. AQUATOOL also allows the definition and simulation of water management at a basin scale and the analysis of alternatives for complex large-scale territories under different scenarios (Pulido-Velazquez et al., 2011).

The simulation with SIMGES is performed at a monthly scale solving a conservative flow network that contains a wide range of elements (introduced as nodes and links in the model): storage elements (reservoirs, lakes, aquifers), transport and diversion paths (rivers with different parameters, channels), transfers between elements (natural runoff inlets, deep percolation, flow discharge from aquifers to rivers) and human interaction processes (conjunctive and non-conjunctive demands, returns, pumping and artificial recharge of aquifers), among others. Surface subsystems are calculated by the continuity equation or simple water balances. Aquifers and their relation with surface elements may be simulated using simple unicellular models, multicellular models, or by distributed linear flow models (Solera et al., 2015). The SIMGES model also computes hydrological processes such as evaporation and infiltration losses from reservoirs and rivers, and the interaction between surface and ground water elements.

The water-resources management processes are simulated by operation rules which try to maintain a similar filling level in reservoirs from reservoir zone curves. Such curves are the operating rules themselves and are usually provided by the user. The model also accounts for both environmental flows and water use priorities.

This model has been used to develop the River Basin Plans in most Spanish River Basin Districts (CHD, 2015; CHT, 2014). Moreover, SIMGES has also been applied to Spanish case studies such as examining the effect of water stressed scenarios (Momblanch et al., 2015), assessing the exploitable water resources (Pedro-Monzonís et al., 2015), diagnosing the effect of climate change and global changes and their impacts (Pouget et al., 2012 and Pulido-Velazquez et al., 2011) and evaluating water quality analysis (Paredes et al., 2010).

\subsection{ASTER (hydrological model related to snow processes)}

ASTER model is a snow-rainfall hydrologic model which simulates and forecasts hydrologic processes related to snow (MAGRAMA, 2015). It makes predictions of the water flows at some closure points

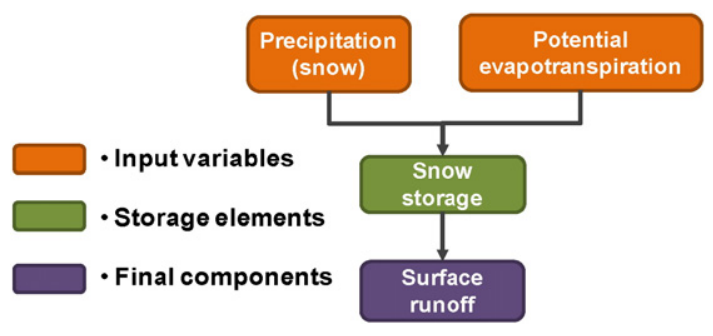

Fig. 2. Schematic structure of ASTER model.

that are usually coincident with the closure points of the basin. The model uses thermo-pluviometric data from weather and river gauging stations and calculates the snow accumulation and fusion rates for a specific date. Thus, it is specially adapted to alpine mountains with snow regimes. The algorithm relies on classical hydrologic deterministic models that are based on snow deposits, for example, the Canadian CEQUEAU (Morin and Paquet, 2007). For designing the snow-melting routine, the studies performed by Anderson and applied in the American NWSRFS of the National Weather Service (Anderson, 1973) have been used as a reference.

Although the model was originally developed at daily resolution, its time step is currently variable. The selected time scale will depend on the objective of the study or on the time resolution of the data which are logged in thermal and rain gauges.

The specific characteristics of the basin are depicted numerically by discretizing in finite elements or cells of variable-size grid with the aid of a Digital Elevation Model (DEM). In this process, each cell should represent a homogeneous elementary area taking into account its slope, orientation, or vegetal ground cover. It has its own runoff direction and its height and surface values and calculations are made for each cell independently. An adequate division in cells is basic so the model can simulate the real response of the basin when raining or snowmelting occurs.

ASTER software requires inputs from the pluviometric accumulated measurements for the working time unit and the average temperature from, at least, one spot of the basin. These registered data together with the physiographical basin description will trigger the model. The hydrological calculations are based on complex equations and contain many parameters that must be modified by comparative analysis of model estimations and the real water flow data. A simplified diagram of the variables involved in the snow ASTER module is included in Fig. 2.

\section{Case study: Duero watershed}

The Duero River basin is the largest of the Iberian Peninsula covering a total area of $98,073 \mathrm{~km}^{2}$. The basin is a transboundary system comprising territories of Spain $\left(78,859 \mathrm{~km}^{2}-80 \%\right.$ of the basin) and Portugal ( $20 \%$ $-19,214 \mathrm{~km}^{2}$ ). The focus of this study is the Spanish side of the basin (Fig. 3) which represents the $15.6 \%$ of the total Spanish territory.

The Duero is a transboundary river between Spain and Portugal. Both countries signed a treaty, called 'Albufeira Convention' (BOE, 2000), which includes regulatory actions for all the basins shared between each other.

Except for the boundary shared with Portugal (located at the west part), the rest of the Duero Spanish area RBS limits the intra-territorial basins (Miño-Sil basin to the northwest, Cantábrico basins to the north, Ebro to the northeast and east and Tajo to the south). Thus, the inflow from upstream territories is null. The population of the basin is about 2.2 million unevenly distributed. While more than $50 \%$ of the population lives in urban areas, the number of villages with less than 1000 inhabitants is large with hardly any town reaching 50,000 people.

The climate basin is Continental Mediterranean, with an average annual rainfall of $612 \mathrm{~mm}$ although the climatic differences within the river basin are significant. Average precipitation ranges from 


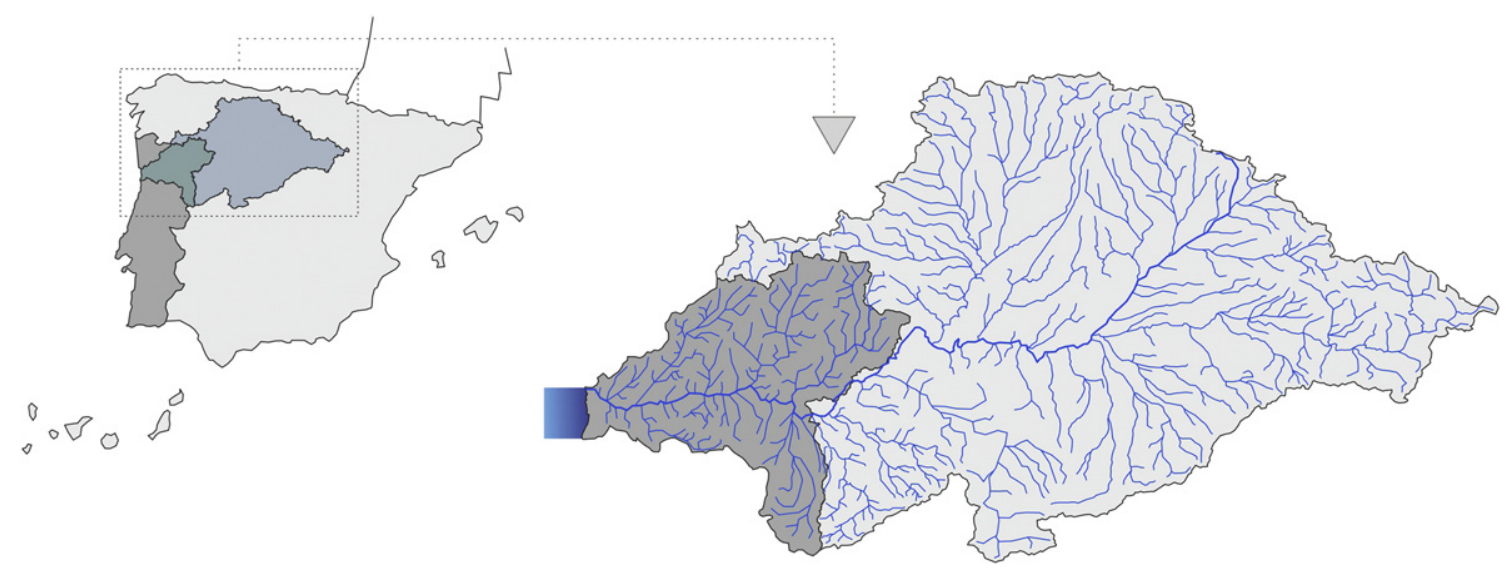

Fig. 3. Duero River basin location

$1800 \mathrm{~mm}$ in the upstream mountains to less than $400 \mathrm{~mm}$ in continental areas in the inner territory. The dry period coincides with warmer temperatures while precipitation is seasonally dependent.

Duero River Basin Authority (CHD by its Spanish acronym) globally manages the water resources in the basin including water planning and allocation among different uses (e.g. irrigation, urban, hydroelectric power), water quality control and management, flood prevention and environmental issues, among others. This entity reports to the Spanish

Table 1

Surface area of subzones and zones of Duero basin.

\begin{tabular}{llll}
\hline Subzones (Exploitation systems) & Area $\left(\mathrm{km}^{2}\right)$ & Zones & Area $\left(\mathrm{km}^{2}\right)$ \\
\hline 1. Támega-Manzanas & 1911.5 & A & $19,301.3$ \\
2. Aliste-Tera & 2920.6 & & \\
3. Órbigo & 4986.5 & & \\
4. Esla-Valderaduey & 9482.7 & & $17,361.9$ \\
5. Carrión & 4977.0 & B & \\
6. Pisuargo & 7055.4 & & $12,924.7$ \\
7. Arlanza & 5329.5 & & $15,680.8$ \\
8. Alto Duero & 8952.7 & C & \\
9. Riaza-Duratón & 3972.0 & & $13,590.8$ \\
10. Cega-Eresma-Adaja & 7884.9 & D & \\
11. Bajo Duero & 7795.9 & & \\
12. Tormes & 7385.5 & E & \\
13. Águeda & 6205.3 & & \\
\hline
\end{tabular}

Ministry of Agriculture, Food, and Environment (MAGRAMA). CHD has divided the watershed into five management units (Zones) and 13 exploitation systems (Subzones) listed in Table 1.

More information about the Duero System can be found at the Duero RBD website (CHD, 2015).

\section{Water balance methodology}

An asset accounts-build process depends on factors such as sources of information, territorial scope, data availability, and degree of uncertainty associated with the values. In the present study, the methodology developed for the water balance is affected by uncertainty of the sources of the available information.

The SEEA-W guidelines recommend the use of officially published information avoiding 'ad hoc' estimations. Thus, most of the input data was gathered from Spanish official sources: CHD, the Ministry of Agriculture, Food and Environment (MAGRAMA), and the Government Ministerial Department. Then all the data were logged into several datasets. The study was made with different levels of disaggregation and it covered 26 years. Thus, the volume of data was huge and a big effort was made during its pre-processing: cleaning, aggregation, standardization and transformation into the requested SEEA-W format.

The processes carried out to build the asset accounts are described below. All the steps and topics treated have been categorized into two

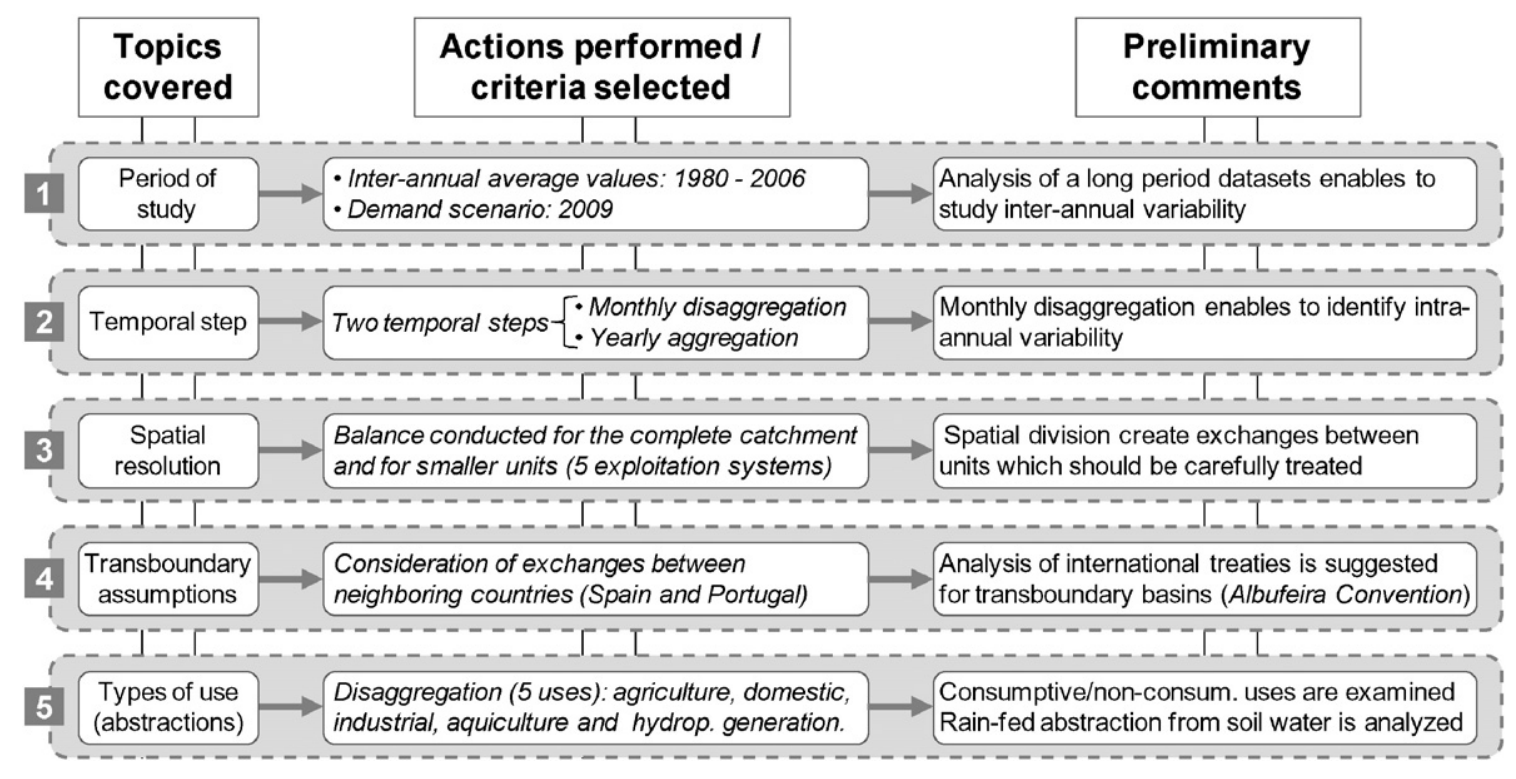

Fig. 4. Summary of topics covered and actions performed through the SEEA-W asset accounts development. 
sections. One addresses the key issues that must be taken into consideration in any study concerning SEEA-W asset accounts and hence could be applied to other studies. The other presents specific issues regarding the methodology developed in this study.

\subsection{General topics for the elaboration of SEEA-W asset accounts}

Regarding the water-balance analysis, five topics have been highlighted: period of study, temporal step units, spatial resolution, transboundary assumptions, and disaggregation into types of water use. Fig. 4 summarizes for each topic, the main actions performed and some relevant comment.

\subsubsection{Period of study}

Taking into account the data analysis, it is important to compile the accounts on a yearly basis. Therefore, a complete hydrological year is the minimum required period. In areas where inter-annual variability of hydrological components may be significant, it is preferred to calculate water asset accounts on a series of inter-annual average values than on a single year. As a general rule, a longer period of study presents more representative and reliable results. When several sources of information are used, the period of study may be determined by the availability of datasets with overlapped years.

In the current study, most data was acquired from the three models described in Section 2, i.e. SIMPA, ASTER, and SIMGES models, each with different periods of data available. Table 2 shows the main features of the datasets associated to each model.

The selection of the period of study was made with the support of CHD, which gave valuable advice to the most suitable datasets in terms of reliability. The water balances were finally based on interannual average values of the SIMPA model (from 1980 to 2006), interannual average values of the complete series of ASTER model, and the 2009 demand scenario of SIMGES model.

\subsubsection{Temporal step}

The time step must be carefully selected. Intra-annual variability of the key variables of the water balance, can lead to choose a smaller time scale resolution than a year, such as a week or more generally, a month. In the Duero catchment, hydrological components such as rainfall, evapotranspiration, runoff, and soil moisture, can vary during a single year in a very significant way. Similarly, water abstractions due to human activities may change during the year, particularly relevant in the case of irrigated agriculture use.

To better evaluate the intra-annual variability, two complementary water balances were developed with different temporal step resolutions. The first estimated the water balance for the complete hydrological period and captured the overall water availability built on interannual averages, and the other estimated considering a monthly time step. This was consistent with the data extracted from SIMPA and SIMGES models that work at this scale, as shown in Table 2. Data related to ASTER model was calculated at daily temporal resolution so the dataaggregation process was required.

\subsubsection{Spatial resolution}

Similarly to time step resolution, no rules apply when selecting a proper spatial scale. Asset accounts for very large basins, without any

Table 2

Available datasets of models used.

\begin{tabular}{|c|c|c|c|c|c|}
\hline MODEL & & $\begin{array}{l}\text { Start period } \\
\text { (Hydrological } \\
\text { year) }\end{array}$ & $\begin{array}{l}\text { End period } \\
\text { (Hydrological } \\
\text { year) }\end{array}$ & $\begin{array}{l}\text { Number } \\
\text { of years }\end{array}$ & $\begin{array}{l}\text { Time } \\
\text { step }\end{array}$ \\
\hline SIMPA & & $1940 / 1941$ & $2009 / 2010$ & 70 & Monthly \\
\hline ASTER & & $2002 / 2003$ & $2013 / 2014$ & 12 & Daily \\
\hline \multirow[t]{2}{*}{ SIMGES } & Input data & $1980 / 1981$ & $2005 / 2006$ & 26 & Monthly \\
\hline & Demand scenarios & \multicolumn{2}{|c|}{$2009 ; 2015 ; 2021 ; 2027$} & 4 & Monthly \\
\hline
\end{tabular}

Table 3

Spatial resolution of models used.

\begin{tabular}{lll}
\hline MODEL & Territorial scope & Type of spatial resolution \\
\hline SIMPA & National territory & Regular grid $1 \mathrm{~km}^{2}$ \\
ASTER & National territory & Alpine sub-basins \\
SIMGES & Duero River basin & Duero exploitation systems \\
\hline
\end{tabular}

disaggregation, may neglect any water resources and water demand variability. On the contrary, a large disaggregation into small areas will not help stakeholders in their water management decisions.

Likewise, each process occurs at different spatial scales. Different key components of the hydrological cycle are associated with differing spatial scale distributions. While some processes are easily distributed throughout the entire catchment (e.g. precipitation, evapotranspiration, or infiltration) others, such as water stored in aquifers, are concentrated in certain areas. Regarding human activities processes, the spatial scale is linked to the exploitation systems operated by water authorities or water users. Another factor of paramount importance is the spatial aggregation of available data.

In this study, the water balances considered two spatial units: the complete catchment and the management zones of CHD (Zones A to E). The datasets for this calculation came mostly from SIMPA, ASTER, and SIMGES models, which were generated with different spatial resolutions as shown in Table 3.

In order to elaborate water balances, the same spatial scale was needed. Thus, the biggest of the three units was selected (CHD management zones), aggregating all the data into this unit. SIMGES datasets were used directly as they were calculated with this spatial resolution. The SIMPA model needed an aggregation process from regular cells to the selected scale. Fig. 5 shows an example of precipitation aggregation: $p_{i, j}$ is the value of precipitation for each cell of the grid; $A_{T}$ is the total area of the management zones; and $P_{i, j}$ is the total precipitation for each management zone after the aggregation process.

Unlike SIMPA, the model ASTER was implemented only in certain areas of the national territory with significant occurrence of snowrelated processes, i.e. the alpine sub-basins. Those sub-basins located within the same management zone were aggregated in a similar way as the process explained for SIMPA model.

\subsubsection{Transboundary assumptions}

When the accounts are compiled for water resources shared by several countries, the part of the shared resources that belongs to each country as well as the origin and destination of specific flows must be explicitly identified. Although the present analysis is carried out only for the Spanish part of Duero River basin, these transboundary assumptions were taken into account.

In the case of Duero basin, inflows from upstream territories are not significant for the Spanish part of the catchment as the major part of water is originated within the territory. Only a small portion of water comes from the neighboring country (Portugal). The flow enters the territory through specific points by small rivers and streams and through distributed areas where surface runoff emerging from Portuguese territory is drained in the Spanish territory (Fig. 6).

On the contrary, regarding outflows from Spain to downstream territories, a significant volume of water enters Portugal. This was considered in several border areas shared by both countries although the greater outflow corresponds to the Duero main river course, as shown in Fig. 6.

International conventions on transboundary water and the European Union Water Framework Directive cover issues related to the quantity of transboundary waters. In particular, regarding the rivers shared by Spain and Portugal, both countries signed a water treaty in 1998: "the Cooperation Agreement for protection and el sustainable harnessing of the Spanish-Portuguese watersheds," better known as 


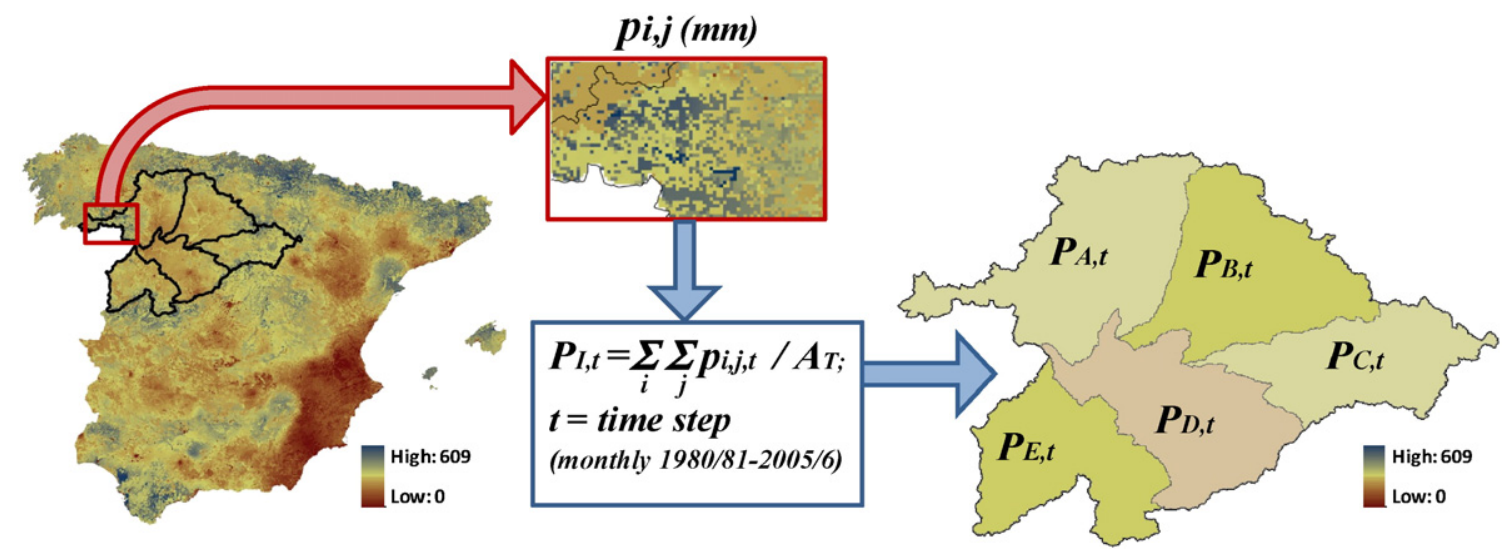

Fig. 5. Spatial aggregation process of SIMPA-model data.

the Albufeira Convention. This convention, seeks to balance sustainable use of the water resources with environmental protection within the framework of EU directives, and applies to their shared basins (Miño, Limia, Duero, Tajo, and Guadiana). One of the main aspects of the Albufeira Convention is the commitment to provide a minimum annual flow set considering the annual hydrological balance. The flow regime is fixed at certain intermediate points and at the final exchange between Spain and Portugal (corresponding to point 'D' of Fig. 6). In this study, flows monitored in the latter point were compared with those estimated by the model.

\subsubsection{Analysis by water uses}

One of the big concerns in the River Basin Plans is associated to the estimation of water resources associated to water users. In this regard, the SEEA-W tables related to 'physical accounts' are used to fulfill the targets set out by the SEEA-W guidance (relate environment accounts with economy) providing a starting point for the elaboration of the economics-related tables. Thus, water abstractions were broken down into water uses. This will facilitate the link between 'asset account' tables with 'supply and use' ones.

The total volume abstracted from the system, from surface and groundwater resources, must represent the amount of water removed either permanently or temporarily for final consumption and production activities, including non-consumptive uses as water used for hydroelectric power generation. Given the large volumes of water abstracted by this activity, it is advisable to identify it separately (both the abstraction and returns from power plants). Consumptive uses were also separated according to the classification introduced by the CHD in its Hydrological Plan: agriculture, urban, industrial, and aquiculture. Specific analysis was made of rain-fed agriculture use and the treatment that SEEA-W guidance (EC, 2012) gives to this component. Discussion related to this topic can be found in a next Section (5.4 Analysis by water uses).

\subsection{Specific issues of the methodology developed}

This section outlines some of the key aspects related to the methodology used in this study that regards, specifically, with the three models used to estimate the SEEAW tables.

\subsubsection{Limitations of the methodology}

Some of the hypotheses adopted to balance the asset accounts properly and its limitations are summarized as follows:

- Despite of using officially published data, consistency of water assets was not always assured if data from different sources were used. This drawback was overcome by maintaining constant communication with the data providing entities that were allowed for each case, either the implementation of the most suitable data or the recalculation whenever deemed appropriate.

- The information requirements of SEEAW asset accounts are very demanding and frequently no direct data are available to fulfill specific

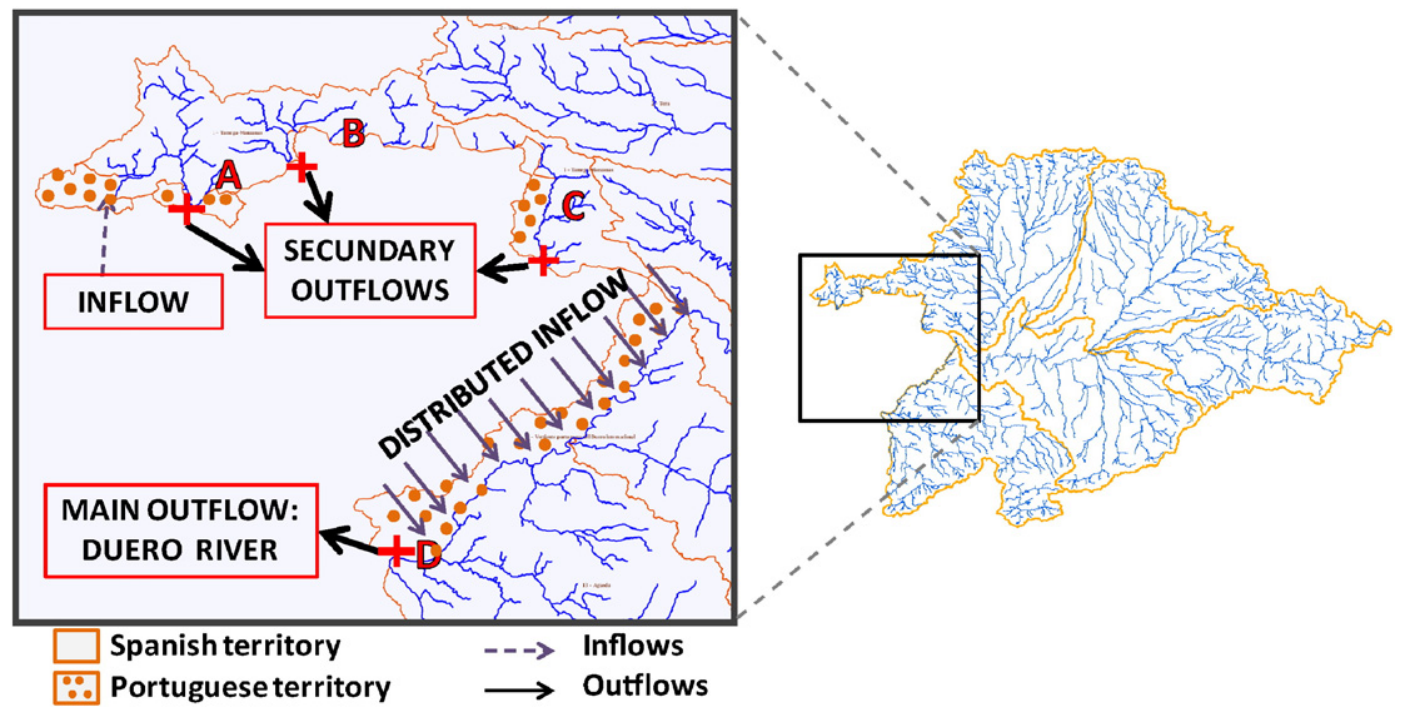

Fig. 6. Flow exchange areas between Spain and Portugal. 
cells of the tables. Thus, some processes were not included in this study. Nevertheless, the processes disregarded are associated with hydrological transfers with low relevance in comparison with the overall balance. Some of them were the following: (a) precipitation into reservoirs, lakes, and rivers (all the water incoming from precipitation has been assumed to fall into soil or in form of snow); (b) deep percolation from lakes to groundwater; (c) exchanges between groundwater bodies (aquifers) from upstream territories and to downstream ones; (d) evaporation from lakes and rivers, and sublimation from snow.

- Values of opening stocks related to certain water bodies (lakes and groundwater) were obtained from CHD rough estimations and distributed proportionally through the catchment. Closing stocks for all water bodies were calculated through the asset accounts balance for the study period.

- As rivers are in constant motion, computing their stocks is not a realistic procedure and therefore was omitted from the accounts.

- Data extracted from hydrological and hydraulic models were mainly used in this study although these models inevitably introduce uncertainty. This are inherent to the techniques and methods for estimating model parameters, the way time and space variability is considered, the goodness of the mathematical expressions that represent hydrological processes, the numerical procedures to solve mentioned equations, and others. Moreover, data sets of certain variables were recalculated in order to properly link the different models used and introduce a certain degree of uncertainty.

\subsubsection{Model-linking}

A procedure was followed to link the three models. The components used to establish these connections were (a) surface runoff to link SIMPA and ASTER models and (b) total runoff to connect SIMPA with SIMGES models. Available data series provided by official entities, CHD and MAGRAMA, were used. Since the models were not integrated in the same platform, some hypothesis and new calculations had to be introduced to connect all of them. The overall relationship is summarized in Fig. 7.

\subsubsection{Migration of data to SEEAW tables}

After all the SEEAW asset accounts were collected, treated, and calculated, the last stage was the migration of the information to their respective place in the tables. It should be noted that certain processes were not considered in the balance. The following tables (Tables 4 and 5) summarize the sources of each cell related to SEEA-W physical account tables: Tables VI.1 (asset accounts) and VI.2 (Matrix flows). A few notes are made:

- Empty cells in color grey means that are processes not included in the present water balance. While dark grey is associated to processes that has little hydrological sense and thereby will not be considered in most asset accounts, light grey are processes that have not been considered in this particular project (due to little relevance or lack of information).

- Estimation - Estimated values. Stocks on lakes and groundwater were based on rough estimations.

- Automatic - These cells are automatically calculated as sum of others cells of the table.

- Table VI.2 - The values of these cells of Table VI.1 are linked to the results of Table VI.2.

\section{Results and discussion}

In this section, the methodology proposed to elaborate SEEA-W asset accounts is applied to the Spanish part of Duero basin with different levels of disaggregation. The results of the overall asset accounts are presented in the next tables (see Tables 6 and 7), following the standards established by SEEA-W guidance (EC, 2012). A number of relevant aspects are also analyzed and discussed related to each sub-section addressed.

\subsection{Analysis of temporal variability through monthly water accounts}

In order to better assess the temporal variability of the basin, a second analysis was conducted with a smaller time step resolution: monthly scale. Fig. 8 shows the values of annual water volume, implemented to the complete Duero catchment, of some relevant hydrological processes: precipitation, total runoff, actual evapotranspiration, and soil storage.

The graphs show both intra-annual and inter-annual variability of each component during the hydrological cycle. While evolution of average values (blue line in the graphs) show a high seasonality and hence intra-annual variability for all the components, the standard deviation values (red-dotted lines) mean a significant inter-annual variability.

Similarly, values related to water abstractions show a clear seasonality throughout the year as depicted in Fig. 9.

Irrigated agriculture is the most significant example, with values close to zero in the winter months and its highest values in summer $\left(115810^{6} \mathrm{~m}^{3}\right)$. Urban use also presents intra-annual changes, increasing the demanded volume of water during summer months (from 30 $10^{6} \mathrm{~m}^{3}$ to $4910^{6} \mathrm{~m}^{3}$ ). On the contrary, aquiculture and other industrial uses do not present particular changes with mean values of $3710^{6}$ and $1710^{6} \mathrm{~m}^{3}$, respectively.

In conclusion, the elaboration of monthly accounts has been proven to be relevant due to the intra-annual variability of hydrological components as well as those processes related to human activities (abstractions and returns).

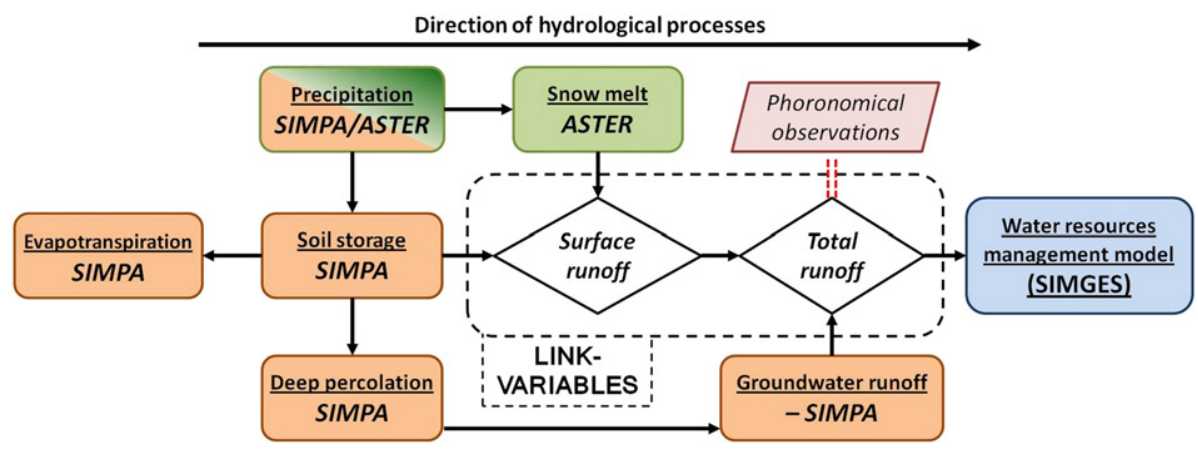

Fig. 7. Highlight of key variables in model-linking process among SIMPA, ASTER, and SIMGES models. 


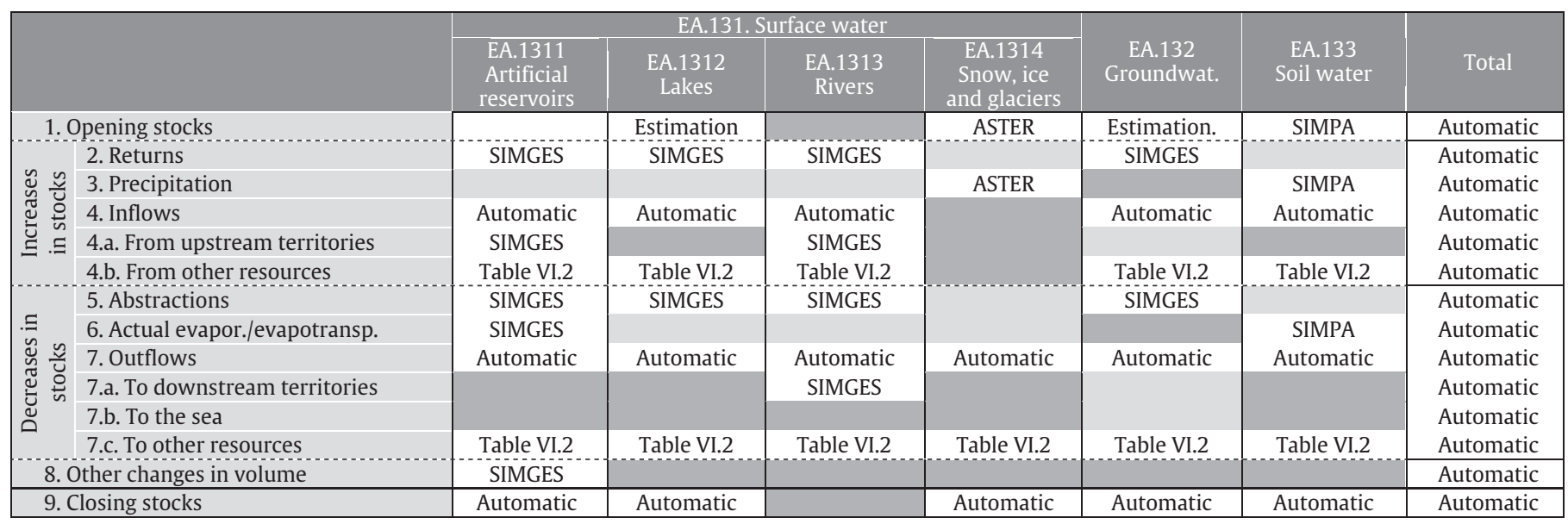

Table 5

SEEA-W Table VI.2 'matrix of flows between water resources': origin of each cell.

\begin{tabular}{|c|c|c|c|c|c|c|c|c|}
\hline & & \multicolumn{4}{|c|}{ EA.131. Surface water } & \multirow[b]{2}{*}{$\begin{array}{c}\text { EA.132 } \\
\text { Groundwat. }\end{array}$} & \multirow[b]{2}{*}{$\begin{array}{c}\text { EA.133 } \\
\text { Soil water }\end{array}$} & \multirow{2}{*}{$\begin{array}{l}\text { Outflow to } \\
\text { other } \\
\text { resources in } \\
\text { the territory }\end{array}$} \\
\hline & & $\begin{array}{c}\text { EA.1311 } \\
\text { Artificial } \\
\text { reservoirs } \\
\end{array}$ & $\begin{array}{l}\text { EA.1312 } \\
\text { Lakes }\end{array}$ & $\begin{array}{l}\text { EA.1313 } \\
\text { Rivers }\end{array}$ & $\begin{array}{c}\text { EA.1314 } \\
\text { Snow, ice } \\
\text { and glaciers }\end{array}$ & & & \\
\hline EA.1311 & Artificial reservoirs & & & \multirow{2}{*}{$\begin{array}{l}\text { SIMGES } \\
\text { SIMGES }\end{array}$} & & \multirow[t]{2}{*}{ SIMGES } & & Automatic \\
\hline EA.1312 & Lakes & & & & & & & Automatic \\
\hline EA.1313 & Rivers & SIMGES & SIMGES & \multirow{4}{*}{$\begin{array}{l}\text { ASTER } \\
\text { SIMGES } \\
\text { SIMPA }\end{array}$} & & \multirow[t]{3}{*}{ SIMGES } & & Automatic \\
\hline EA.1314 & Snow, ice and glaciers & & & & & & & Automatic \\
\hline EA.132 & Groundwater & & & & & & SIMPA & Automatic \\
\hline EA.133 & Soil water & SIMPA & SIMPA & & & SIMPA & & Automatic \\
\hline \multicolumn{2}{|c|}{ Inflows from other resources in the terr. } & Automatic & Automatic & Automatic & Automatic & Automatic & Automatic & Automatic \\
\hline
\end{tabular}

\subsection{Spatial disaggregation discussion}

Following SEEA-W standards, the territory was split into smaller areas to provide more comprehensive results. The selected units were the management zones of Duero basin, as are divided by
CHD in its Water Basin Plan. However, the division of the complete catchment into smaller units originated "artificial divides" between sub-basins which had to be treated as potential points of flow exchange between territories. Similarly to the transboundary exchanges between countries shown in Fig. 6 (see Section 4.1.4

Table 6

SEEA-W Table VI.1 'asset accounts': overall balance.

\begin{tabular}{|c|c|c|c|c|c|c|c|c|c|}
\hline \multirow{2}{*}{\multicolumn{3}{|c|}{\begin{tabular}{|ll} 
Territory: & Duero System \\
Time step: & Year
\end{tabular}}} & \multicolumn{4}{|c|}{ EA.131. Surface water } & \multirow{4}{*}{$\begin{array}{c}\text { EA.132 } \\
\text { Groundwat. }\end{array}$} & \multirow{4}{*}{$\begin{array}{c}\text { EA.133 } \\
\text { Soil water }\end{array}$} & \multirow{4}{*}{ Total } \\
\hline & & Year & \multirow{3}{*}{$\begin{array}{c}\text { EA.1311 } \\
\text { Artificial } \\
\text { reservoirs } \\
\end{array}$} & \multirow{3}{*}{$\begin{array}{l}\text { EA.1312 } \\
\text { Lakes }\end{array}$} & \multirow{3}{*}{$\begin{array}{c}\text { EA.1313 } \\
\text { Rivers }\end{array}$} & \multirow{3}{*}{$\begin{array}{c}\text { EA.1314 } \\
\text { Snow, ice } \\
\text { and glaciers } \\
\end{array}$} & & & \\
\hline Period: & 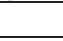 & $1980 / 2006$ & & & & & & & \\
\hline Water & ses: & Aggregated & & & & & & & \\
\hline \multicolumn{3}{|c|}{ 1. Opening stocks } & 3490 & 200 & & 0 & 400 & 292 & 4382 \\
\hline \multirow{5}{*}{ 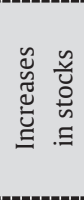 } & 2. Ret & urns & 196 & 0 & 58157 & & 0 & & 58353 \\
\hline & 3. Pre & cipitation & & & & 6354 & & 46232 & 52586 \\
\hline & 4. Inf & ows & 24417 & 136 & 19376 & & 2333 & 0 & 46262 \\
\hline & 4.a. $\mathrm{F}$ & rom upstream territories & 0 & & 0 & & & & 0 \\
\hline & 4.b. F & rom other resources & 24417 & 136 & 19376 & & 2333 & 0 & 46262 \\
\hline \multirow{6}{*}{ 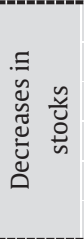 } & 5. Ab & stractions & 17127 & 0 & 43576 & & 1235 & & 61938 \\
\hline & 6. Act & ual evapor./evapotranspirat. & 194 & & & & & 33391 & 33585 \\
\hline & 7. Ou & tflows & 7300 & 136 & 33249 & 6354 & 580 & 7698 & 55317 \\
\hline & 7.a. $\mathrm{T}$ & o downstream territories & & & 9055 & & & & 9055 \\
\hline & 7.b. $\mathrm{T}$ & the sea & & & & & & & 0 \\
\hline & 7.c. $\mathrm{T}$ & other resources & 7300 & 136 & 24194 & 6354 & 580 & 7698 & 46262 \\
\hline \multicolumn{3}{|c|}{ 8. Other changes in volume } & 0 & & & & & & 0 \\
\hline \multicolumn{3}{|c|}{ 9. Closing stocks } & 3481 & 200 & & 0 & 918 & 292 & 4892 \\
\hline
\end{tabular}


Table 7

SEEA-W Table VI.2 'matrix of flows between water resources': overall balance.

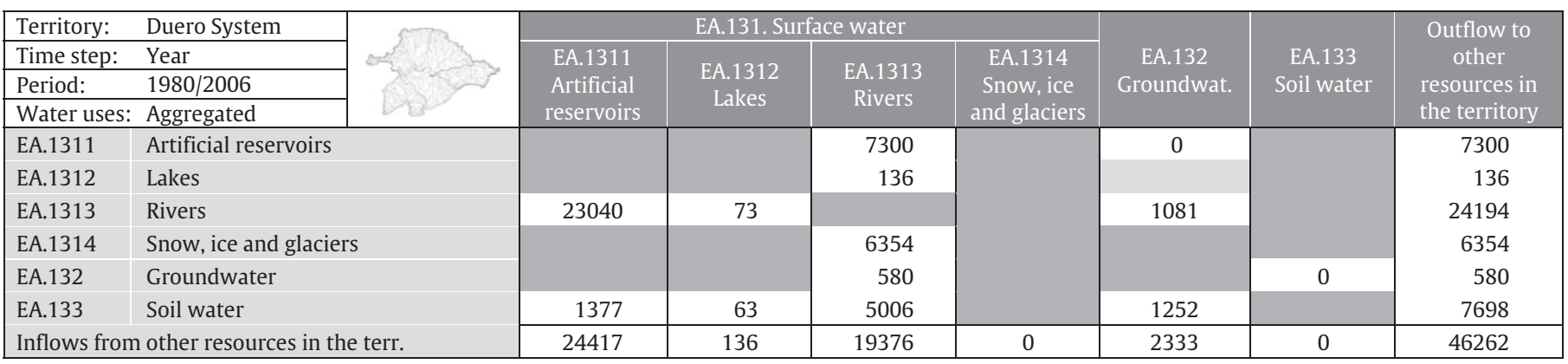

Transboundary assumptions), these "artificial divides" can represent connections through concentrated points (main course of rivers and streams) or through distributed areas (surface runoff emerged from one territory and drained into another). Fig. 10 shows graphically the potential hydraulic connections between each split territory.

In the present study, only punctual transfers through rivers or artificial channels were taken into account, disregarding those possible distributed inflows/outflow caused by direct runoff. Table 8 shows the volumes of water exchanged between management zones, calculated through inter-annual average values.
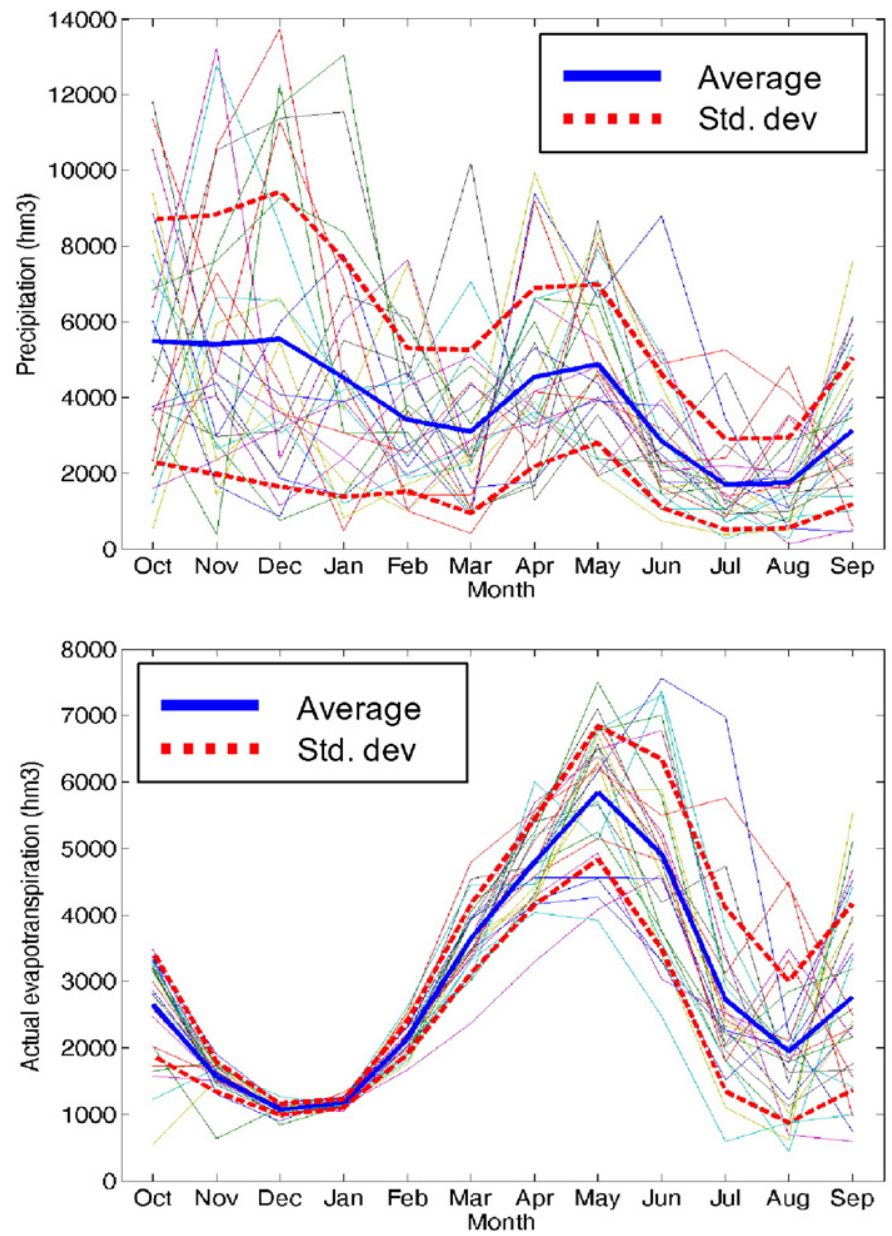

All the exchanges between management zones had to be introduced in 'SEEA-W asset accounts table' to avoid imbalances in the asset accounts. The potential cells to include these flows were the following: (a) from upstream/to downstream territories, (b) from other resources, or (c) other changes in volume. The authors considered that the inclusion of these values in the current table may lead to confusion. The solution proposed was the introduction of two new terms, for both increases and decreases in stock sections (Table 9). Increases from upstream territories and decreases to downstream ones, were divided into two subheadings: adjacent international territories (neighboring countries) and adjacent territories from the basin itself.
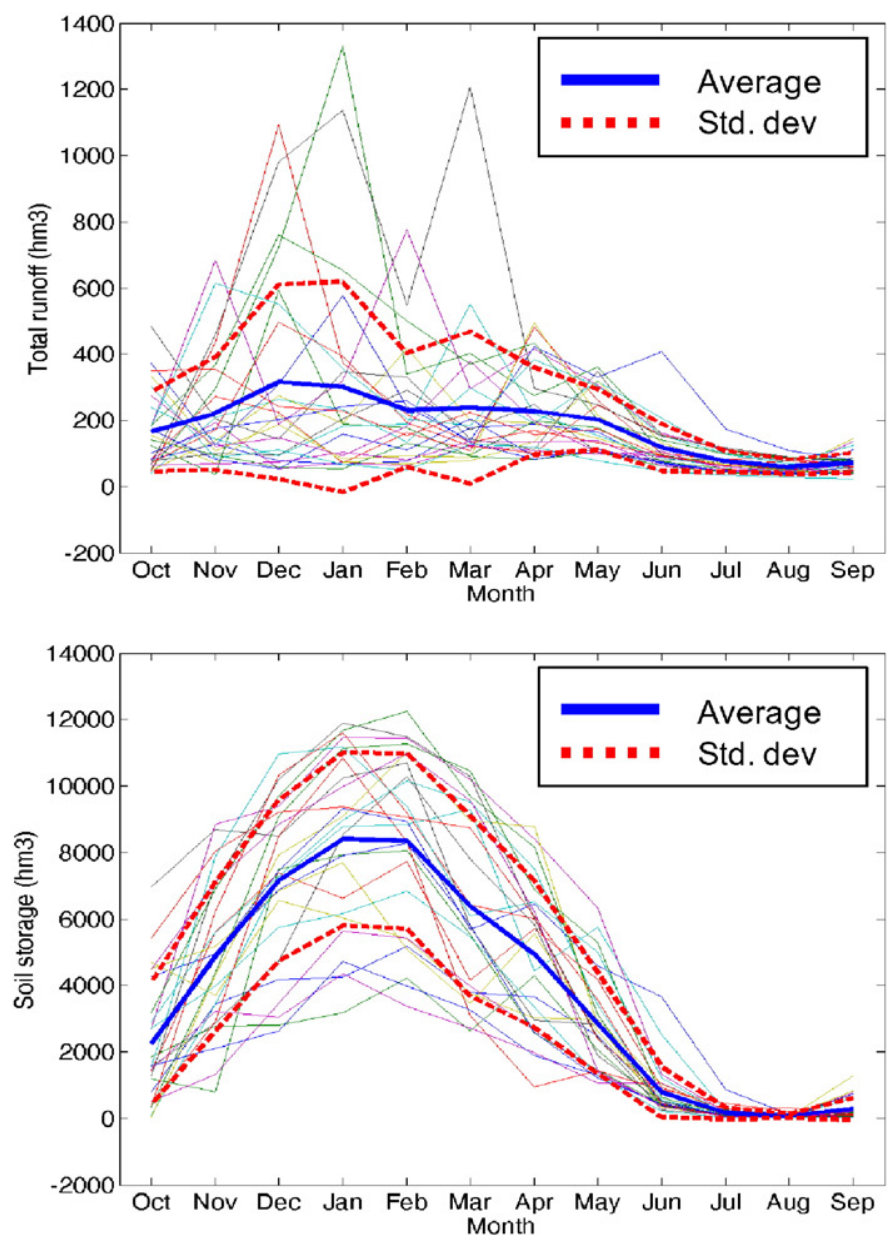

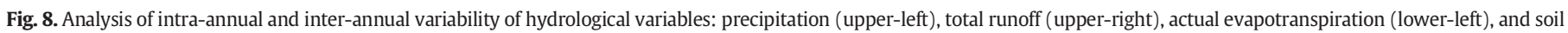
storage (lower-right). 


\section{Annual evolution of abstractions by water uses $\left(\mathrm{hm}^{3}\right)$}

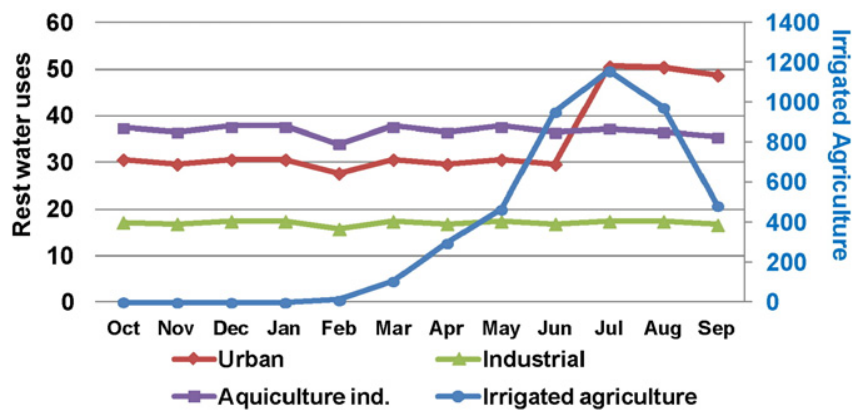

Fig. 9. Evolution during the year of water demands categorized by uses.

\subsection{Transboundary assumptions}

Despite the fact that the present study was focused on the Spanish side of Duero basin, particular attention was drawn to the outflows to Portuguese territory. Apart from the assets calculated and depicted in the overall balance, the analysis was extended with a comparison between simulated outflows with Albufeira Convention committed flows (Fig. 11). Results show how, for all study periods, Albufeira commitments were fulfilled for both annual and quarter outflows.

\subsection{Analysis by water uses}

Finally, a breakdown balance is presented considering the water uses regarding the classification followed by the CHD (agriculture, urban/domestic, aquiculture industry, other industrial uses, and hydroelectric power generation).

Non-consumptive use constitutes the main type of water use in the Duero basin with more than $90 \%$ of the total used water. Regarding consumptive abstractions, irrigated agriculture highlights the rest water uses managed in the study.

With regard to the component of rain-fed agriculture, the authors consider that its treatment should be discussed more thoroughly in the SEEA-W guidance (EC, 2012). This guidance considers the water use in rain-fed agriculture as an 'abstraction' from soil water and it should be computed "as the amount of precipitation that falls onto
Table 8

Volume of water exchanged between management zones for a complete year.

\begin{tabular}{|c|ccccc|}
\hline To & Zone A & Zone B & Zone C & Zone D & Zone E \\
\hline Zone A & & 52 & - & - & 4119 \\
\hline Zone B & - & & - & 1895 & - \\
\hline Zone C & - & 998 & & - & - \\
\hline Zone D & - & - & - & & 2892 \\
\hline Zone E & - & - & - & - & \\
\hline
\end{tabular}

Table 9

Subheadings proposed to introduce exchanges from other territories of the same basin.

\begin{tabular}{ll}
\hline Increases in stocks & 2. Returns \\
& 3. Precipitation \\
& 4. Inflows \\
& 4.a. From upstream territories (adjacent countries) \\
& 4.b. From upstream territories (adjacent sub-basins) \\
& 4.c. From other resources \\
& 5. Abstractions \\
Decreases in stocks & 7. Actual evaporation/evapotranspiration \\
& 7.a. To downstream territories (adjacent countries) \\
& 7.b. To downstream territories (adjacent sub-basins) \\
& 7.c. To the sea \\
7.d. To other resources
\end{tabular}

agricultural fields". The excess of water, which has not been absorbed by the crop, should be recorded "as a return flow into the environment from rain-fed agriculture".

This definition might be inconsistent with some hydrological models such as SIMPA. This model calculates soil storage as a balance between inflows (precipitation) and outflows (evapotranspiration, surface runoff, and deep percolation processes). Thus, in this study rain-fed was assumed to be equivalent to evapotranspiration instead of considering it a soil water abstraction. Under this assumption, Fig. 12 compares results whether rain-fed agriculture would be included or not.

Likewise, the inclusion of both terms (rain-fed use and evapotranspiration) would be redundant. Accordingly, the excess of water was handled as a flow transfer between water bodies (from soil water toward, generally, rivers), instead of a return to the environment. Returns from agriculture use to the environment (aquifers recharge) were considered only for irrigated agriculture. This process was included in the SIMGES model.

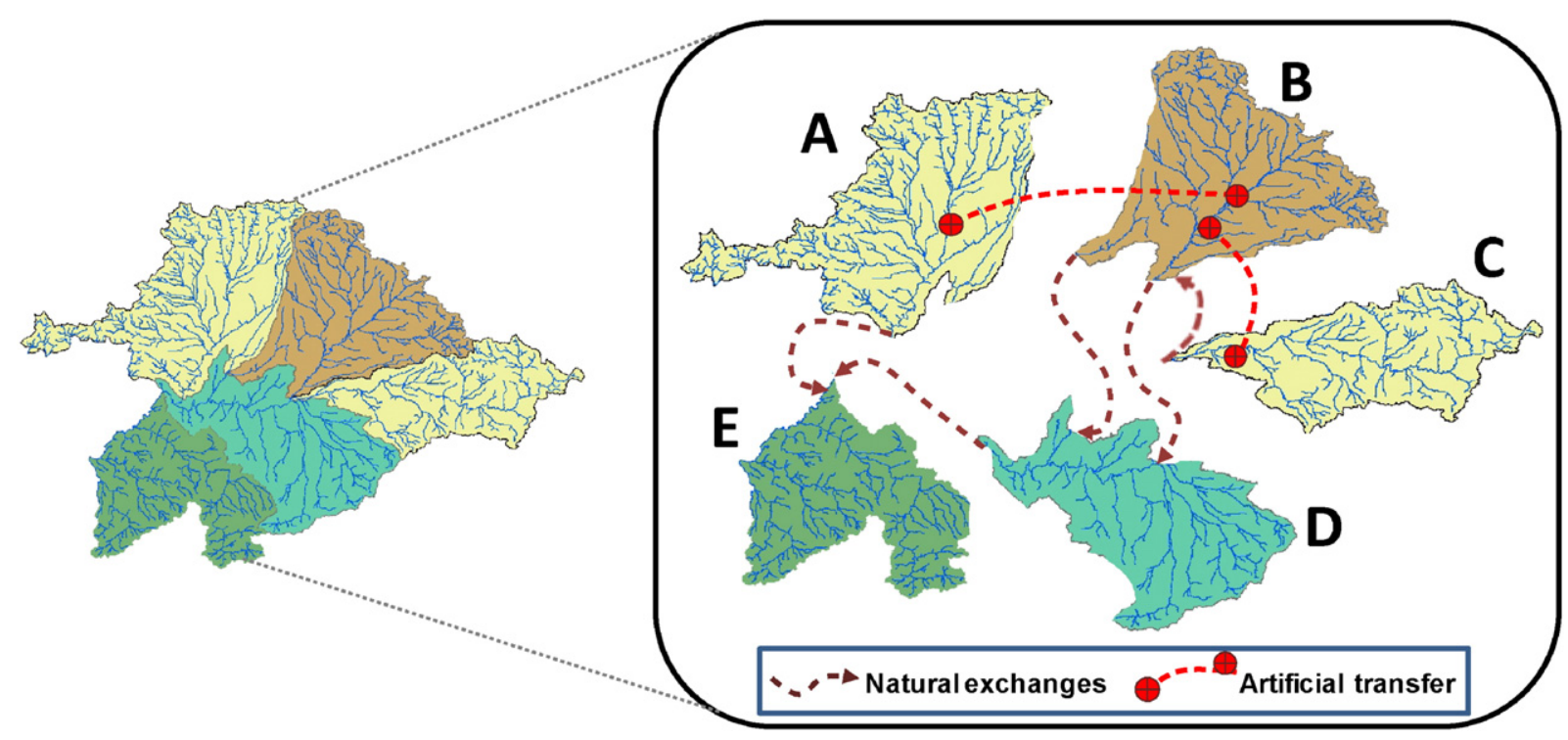

Fig. 10. Spatial disaggregation process and connections between territories. 


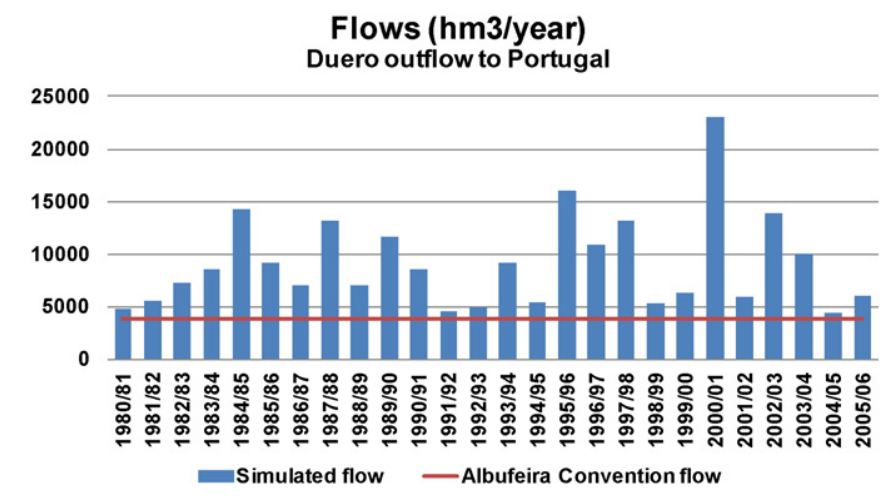

Fig. 11. Volume of annual outflows from Spain to Portugal and comparison with 'Albufeira' commitments.

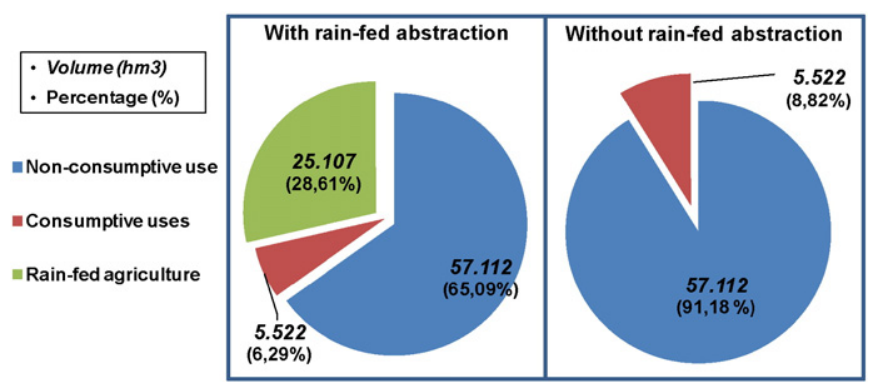

Fig. 12. Comparison between consumptive and non-consumptive abstractions and rainfed agriculture use.

\section{Conclusions}

The System of Environmental-Economic Accounting for Water (SEEA-W) can be considered a useful methodology for standardizing concepts and methods in water accounting to provide a conceptual framework for organizing economic and environmental information in alignment with Water Framework Directive objectives. Nevertheless, the level of detail needed in terms of data requirements is very demanding. The accuracy of the analysis will differ from territory to territory depending on the data availability. This need of obtaining comprehensive information implies a great effort during the data gathering phase. Thus in most cases, support from official entities, which manage the required information, would be very valuable. For the pilot basin of this project, two public-entities have shared information: Duero's Water Basin Authority (CHD) and the Spanish Ministry of Agriculture (MAGRAMA). Transboundary basins, as Duero, would need coordination between countries to integrate information on water balance or otherwise, differences on data availability may result in different water balances for each part.

The present study has applied SEEA-W methodology to the Spanish part of Duero basin for the period 1980 to 2006, with a focus on the physical asset accounts. The water balances were calculated based on inter-annual averages of this period. Additional water balances were estimated with different levels of disaggregation: temporal, spatial, and by water uses.

The two temporal resolutions used, monthly and yearly, were adequate for the water balance. Monthly disaggregation enabled to identify significant intra-annual variability in the Duero River basin. However, yearly-aggregated balances would better support the decisions of water authorities and other stakeholders on planning and management of water resources.

With regard to spatial scale, misleading aspects have been found when elaborating SEEA-W physical accounts. While the analysis conducted for the complete territory was found to be adequate, the division into smaller units highlighted relevant drawbacks. Each division introduced "artificial divides" among spatial units which were not welldefined in the physical tables. Flow exchanges between the different units must be considered in order to balance the asset accounts properly. New terms are proposed to be included in SEEA-W tables to avoid confusion with similar concepts of water exchange. Finally, the disaggregation of a basin into smaller units is not recommended for all the cases unless the basin has a high spatial variability (e.g., very large basins or territories with very high orographic differences).

Most elements or hydrological processes of the SEEA-W tables are very difficult to fill out based on measured data, especially for large basin case studies (e.g., evapotranspiration, soil water, exchanges between water bodies,). As a result, the use of hydrological and hydraulic models is highly recommended. In this study, three models elaborated and validated by different Spanish entities (SIMPA, ASTER, and SIMGES) were applied, showing to be reliable tools for the elaboration of water accounts under the SEEA-W methodology. However, since these models are not integrated in the same platform and that they were created for different purposes, there is a challenge to link them properly. For that purpose, some hypotheses were assumed and some uncertainty inevitably arose. Other drawbacks were the availability of datasets for the same period and the data format and resolution of the results. Although the methodology proposed has limitations, it could be a very valuable tool for its implementation in other Spanish basins since the information from the models used is available for almost all the Spanish basins. Moreover, the use of this procedure may lay the basis for the elaboration of an integral modeling platform at European level that supports the elaboration of SEEA-W tables in a standard form.

The analysis by water uses has set the initial steps for future work that will enable the link between physical water asset accounts and economic tables such as the SEEA-W physical supply and use tables. Abstractions were first disaggregated into consumptive and nonconsumptive uses because of the different consequences on their interaction with the environment. Non-consumptive use, associated in Duero basin to hydropower energy generation, represents the major part of water abstracted with a $91.18 \%$ of the total volume. Of the remaining water uses, consumptive ones, irrigated agriculture is the major use with $80.70 \%$.

Particular focus deserves the handling of rain-fed by SEEA-W methodology defined as an "abstraction from the soil". In view of the relevance of rain-fed agriculture to its contribution to food production, it would be appropriate to consider this flow as a water use. However, this contrasts with the actual evapotranspiration term, which usually includes rain-fed agriculture component in most hydrological models, as the one used in this study (SIMPA model). To avoid redundant accounts and misleading terminology, it would be better to split evapotranspiration into two new terms: evapotranspiration of rain-fed agriculture, which should be computed as an abstraction from human activities, and evapotranspiration of forestry, pastures, and other natural resources, which should be computed as actual evapotranspiration.

\section{Acknowledgements}

The authors would like to thank the European Commission for the funding received for this research through project DUERO RIVER BASIN: WATER RESOURCES, WATER ACCOUNTS AND TARGET SUSTAINABILITY INDICES, DURERO, Grant Agreement: 07.0329/2013/ 671322/SUB/ENV. They would also thank Ángel J. González and Ignacio Rodríguez from the Hydrological Planning Office of Duero Basin Authority (CHD) and the Spanish Ministry of Agricultural, Food and Environment (MAGRAMA) for their support.

\section{References}

ABS (Australian Bureau of Statistics), 2004. Water Account for Australia, 2000-01 (ABS Catalogue No. 4610.0) 0-642-47942-9. 
Álvarez, J., Sánchez, A., Quinta, L., 2004. SIMPA, a GRASS based tool for hydrological studies. Proceedings of the FOSS/GRASS users Conference, Bangkok, Thailand, 12-14 September 2004.

Anderson, E.A., 1973. National Weather Service river forecast system-snow accumulation and ablation model. NOAA Technical Memorandum NWS HYDRO-17. Office of Hydrology, National Weather Service, NOAA, Silver Spring, Md.

Andreu, J., Capilla, J., Sanchís, E., 1996. AQUATOOL, a generalized decision support system for water-resources planning and management. J. Hydrol. 177, 269-291.

BOE (Boletín Oficial del Estado), 2000. Convention on Cooperation for the Protection and Sustainable Use of Water of the Hydrographic Watershed Hispano-Portuguese (BOE $\left.n^{\circ} 37,12 / 02 / 2000\right)$. Albufeira Convention.

BoM (Bureau of Meteorology), 2012. Australian Water Accounting Standard 1: Preparation and Presentation of General Purpose Water Accounting Reports. Commonwealth of Australia (Bureau of Meteorology) 978-0-642-70629-4.

CHD (Confederación Hidrográfica del Duero), 2015. Plan hidrológico de la parte española de la D.H.Duero (2015-2021). Official Report, CHD.

CHT (Confederación Hidrográfica del Tajo), 2014. Plan hidrológico de la parte española de la demarcación hidrográfica del Tajo (2009-2015). Official Report, CHT.

de Miguel, Á., Kallache, M., García-Calvo, E., 2015. The water footprint of agriculture in Duero River Basin. Sustainability 7 (6), 6759-6780.

EC (European Commission), 2003. Handbook of national accounting: integrated environmental and economic accounting 2003, studies in methods, series F, no. 61, rev. 1 Available from http://unstats.un.org/unsd/envaccounting/seea2003.pdf.

EC (European Commission), 2009. White Paper. Adapting to Climate Change: Towards a European Framework for Action. COM, Brussels (2009. 147 final)

EC (European Commission), 2012. A blueprint to safeguard Europe's Water resources. European Commission, 14.11.2012 COM (2012) 673 Final, Brussels.

EP (European Parliament), 2000. Directive 2000/60/EC of the European Parliament and of the Council of 23 October 2000 Establishing a Framework for Community Action in the Field of Water Policy. Official Journal L 327, 22-12-2000, Brussels.

Estrela, T., Quintas, L., 1996. A distributed hydrological model for water resources assessment in large basins. Proceedings of 1st International Conference on Rivertech. Vol. 96, pp. 861-868.

Gonzalez-Zeas, D.P., Garrote de Marcos, L., Iglesias Picazo, A., Sordo Ward, A., 2012. Improving runoff estimates from regional climate models: a performance analysis in Spain. Hydrol. Earth Syst. Sci. 16 (6), 1709-1723.

ICCP (Intergovernmental Panel on Climate Change), 2014. Climate change 2014: impacts, adaptation, and vulnerability. http://www.ipcc.ch/report/ar5/wg2/ (date last accessed: Dec. 20, 2015).

Iglesias, A., Garrote, L., Flores, F., Moneo, M., 2007. Challenges to manage the risk of water scarcity and climate change in the Mediterranean. Water Resour. Manag. 21 (5), 775-788.

Karimi, P., Bastiaanssen, W.G.M., Molden, D., 2013. Water Accounting Plus (WA+) - a water accounting procedure for complex river basins based on satellite measurements. Hydrol. Earth Syst. Sci. 17 (7).

Ludwig, R., Roson, R., 2016. Climate change, water and security in the Mediterranean: introduction to the special issue. Sci. Total Environ. 543 (2016), 847-850.

MAGRAMA (Spanish Ministry of Agricultural, Food and Environment), 2015n. El modelo ASTER; Evaluación de recursos hidráulicos, modelo hidrológico ASTER. MAGRAMA.

Milano, M., Ruelland, D., Dezetter, A., Fabre, J., Ardoin-Bardin, S., Servat, E., 2013. Modeling the current and future capacity of water resources to meet water demands in the Ebro basin. J. Hydrol. 500, 114-126.
MMA (Ministry of Agriculture and Environment), 2000. In: Centro de Secretaría généra Técnica, Ministeri deMedio Ambiente Publicaciones (Ed.), Libro blanco del agua en España. ISBN: 84-8320-128-3 (637 pp.).

Molden, D., Sakthivadivel, R., 1999. Water accounting to assess use and productivity of water. Int. J. Water Resour. Dev. 15 (1-2), 55-71. http://dx.doi.org/10.1080/ 07900629948934.

Momblanch, A., Andreu, J., Paredes-Arquiola, J., Solera, A., Pedro-Monzonís, M., 2014 Adapting water accounting for integrated water resource management. The Júcar Water resource system (Spain). J. Hydrol. 519, 3369-3385.

Momblanch, A., Paredes-Arquiola, J., Munné, A., Manzano, A., Arnau, J., Andreu, J., 2015. Managing water quality under drought conditions in the Llobregat River Basin. Sci. Total Environ. 503, 300-318.

Morin, G., Paquet, P., 2007. Modèle hydrologique CEQUEAU. Rapport de recherche no R000926, INRS-ETE. ISBN: 978-2-89146-538-0.

Paredes, J., Andreu, J., Solera, A., 2010. A decision support system for water quality issues in the Manzanares River (Madrid, Spain). Sci. Total Environ. 408 (12), 2576-2589.

Pedro-Monzonís, M., Ferrer, I., Solera, A., Estrela, T., Paredes-Arquiola, I., 2015. Key issues for determining the exploitable water resources in a Mediterranean river basin. Sci. Total Environ. 503, 319-328.

Pouget, L., Escaler, I., Guiu, R., Mc Ennis, S., Versini, P.A., 2012. Global change adaptation in water resources management: the water change project. Sci. Total Environ. 440 186-193.

Pulido-Velazquez, D., Garrote, L., Andreu, J., Martin-Carrasco, F.J., Iglesias, A., 2011. A methodology to diagnose the effect of climate change and to identify adaptive strategies to reduce its impacts in conjunctive-use systems at basin scale. J. Hydrol. 405 (1), 110-122.

Quevauviller, P., 2014. European water policy and research on water-related topics-an overview. J. Hydrol. 518, 180-185.

Quevauviller, P., Barceló, D., Beniston, M., Djordjevic, S., Harding, R.J., Iglesias, A., Ludwing R., Navarra, A., Navarro Ortega, A., Mark, O., Roson, R., Sempere, D., Stoffel, M., van Lanen, H.A.J., Werner, M., 2012. Integration of research advances in modelling and monitoring in support of WFD river basin management planning in the context of climate change. Sci. Total Environ. 440, 167-177.

Solera, A., Paredes, J., Andreu, J., 2015. Aquatool +, entorno de desarrollo de sistemas de ayuda a la decisión en materia de planificación de la gestión de cuencas hidrográficas incluyendo utilización conjunta y criterios de calidad de aguas. User manual v1.0, 2015.

Témez, J.R., 1977. Modelo matemático de transformación-Aportación. ASINEL Asociación de Investigación Industrial Eléctrica (39pp.).

UN (United Nations), 1993. Handbook of National Accounting: integrated environmenta and economic accounting, interim version. Studies in methods, series F, no. 61. Sales no. E.93. XVII.12. Available from http://unstats.un.org/unsd/publication/SeriesF/ SeriesF 61E.pdf.

UNSD (United Nations Statistics Division), 2012. System of Environmental-Economic Accounting for Water. United Nations, Department of Economic and Social Affairs - Statistics Division, New York (2012).

van Dijk, A., Mount, R., Gibbons, P., Vardon, M., Canadell, P., 2014. Environmental reporting and accounting in Australia: progress, prospects and research priorities. Sci. Total Environ. 473, 338-349. 